\title{
Forbidden to Drive - a New Chemotherapy Side Effect
}

\section{Zákaz řízení - nový vedlejší účinek chemoterapie}

\author{
Rovere R. K. ${ }^{1}$, Silva de Lima A. ${ }^{2}$ \\ ' Department of Medical Oncology, Santo Antonio Hospital, Blumenau, Santa Catarina, Brazil \\ ${ }^{2}$ Medical dermatologist, private practice, Brusque, Santa Catarina, Brazil
}

\begin{abstract}
Summary
Background: Capecitabine is an oral antineoplastic agent classified as a pyrimidin analogue. It is widely used in different types of cancers. Unfortunately, it does not come without a cost, as the drug may have adverse effects - largely diarrhea, but also hand-foot syndrome and loss of fingerprints in extreme cases. Case: We report a case of a 47-year-old male, which had been diagnosed with metastatic rectal cancer and received capecitabine, developing a severe hand foot syndrome which led him to lose his fingerprints in spite of complete resolution of the syndrome after stoppage of the drug. Conclusion: This case highlights a rare condition that, even though not precisely a disease per se, may hinder patient's quality of life and must be recognised by the treating physician as an treatment related side effect.
\end{abstract}

\section{Key words}

capecitabine - fingers - fluorouracil/adverse effects - fluorouracil/analogs and derivatives humans - male - skin/drug effects

\section{Souhrn}

Východiska: Kapecitabin je perorální cytostatikum řezené mezi pyrimidinová analoga. Je široce používán u různých typů nádorů. Bohužel, není neškodný, mívá nepříznivé vedlejší účinky nejčastěji průjem, ale také syndrom ruka-noha, v extrémních prípadech se ztrátou otisků prstů. Případ: Popisujeme prípad 47letého muže, u kterého byl diagnostikován metastazující karcinom rekta a dostal kapecitabin, po kterém se rozvinul těžký syndrom ruka-noha, který vedl ke ztrátě otisků prstů navzdory úplnému ústupu syndromu po zastavení léčby. Závěr: Tento prípad upozorňuje na vzácný problém, které sice není nemocí sám o sobě, ale snižuje kvalitu života pacienta a musí být ošetřujícím lékařem považován za vedlejší účinek léčby.

\section{Klíčová slova}

kapecitabin - prsty - fluorouracil/vedlejší účinky - fluorouracil/analoga a derivativy - lidé muž - kůže/účinky léků
The authors declare they have no potential conflicts of interest concerning drugs, products, or services used in the study.

Autoři deklaruji, že $v$ souvislosti s předmětem studie nemaji žádné komerční zájmy.

The Editorial Board declares that the manuscript met the ICMJE recommendation for biomedical papers.

Redakční rada potvrzuje, že rukopis práce splnil ICMJE kritéria pro publikace zasílané do biomedicínských časopisů.

$\varliminf^{\circ}$

Rodrigo Kraft Rovere, MD

Oncology Unit

Santo Antonio Hospital

Rua Itajai 545

Blumenau, Santa Catarina

CEP 89050100

Brazil

e-mail: rodrigorovere@hotmail.com

Submitted/Obdrženo: 28. 6. 2015

Accepted/Přijato: 27. 8. 2015

http://dx.doi.org/10.14735/amko2015370 


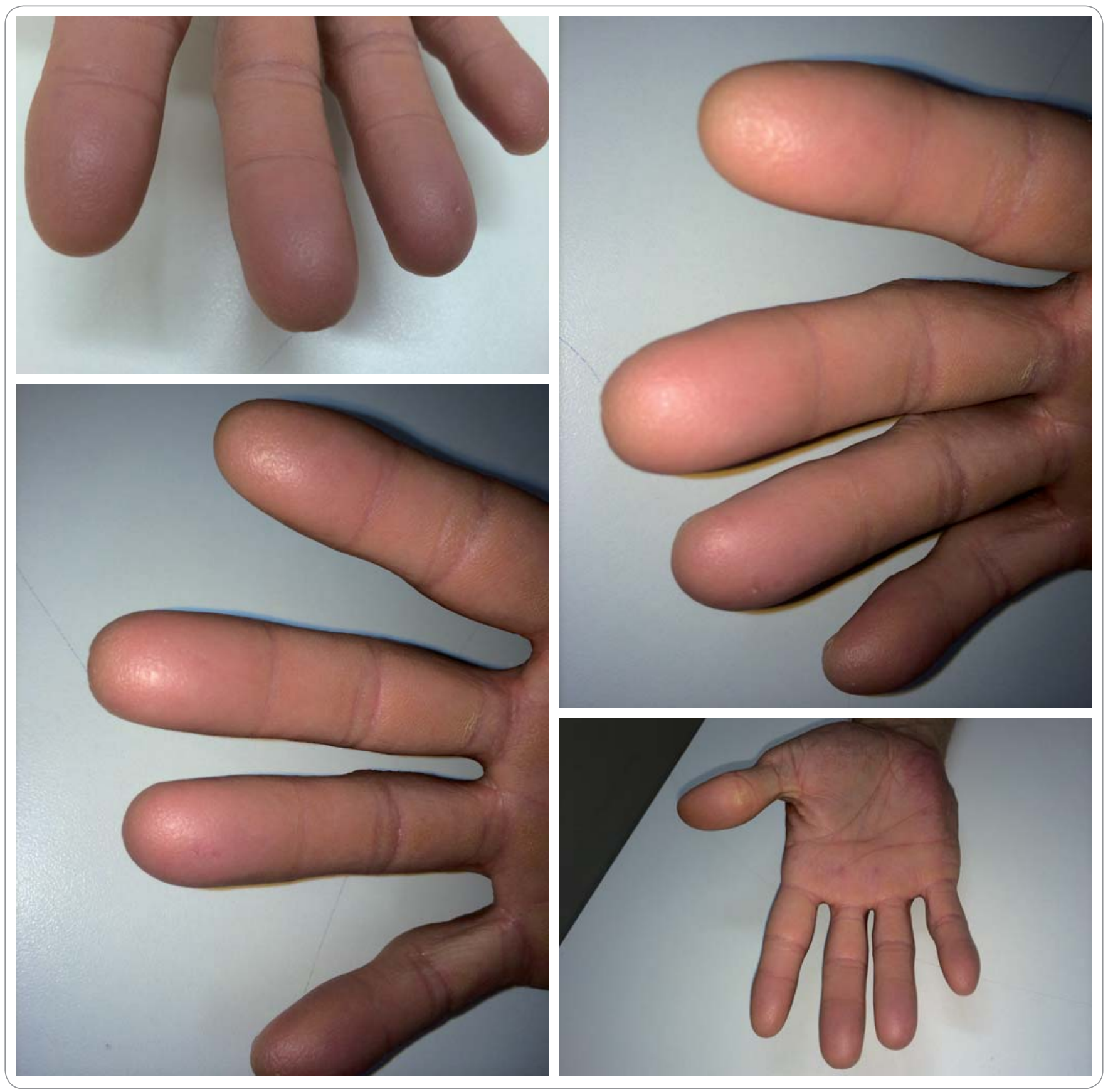

Fig. 1. Complete erasure of the fingerprints.

Capecitabine is an oral antineoplastic agent classified as a pyrimidin analogue. It is widely used in breast [1] and colorectal cancers [2], among others. Unfortunately, it does not come without a cost, as the drug may have adverse effects - largely diarrhea, but also hand-foot syndrome [3].

More than hand-foot syndrome, which usually gives the patient a full recovery after the drug stoppage, continous use of capecitabine may uncommonly lead to loss of fingerprints, as has been already reported [4].

We report a case of a 47-year-old male, who had been diagnosed with metastatic rectal cancer in October 2013. He underwent surgery of the primary tumour to avoid local obstruction, with liver and peritoneal implants at the diagnosis. After receiving initially FOLFOX as first-line therapy, with good clinical response, the patient developed a severe grades III/IV peripheral neuropathy which made impossible further oxaliplatin-based treatment.

At the time, the patient refused any intravenous therapy, so we decided to give capecitabine monotherapy as it was the only available option.

The patient used it for about eight months, starting with $2,000 \mathrm{mg} / \mathrm{m}^{2}$ daily. Soon, he developed hand-foot syndrome, 
initially mild (grade I) but eventually evolving into moderate to severe (grade IV), which prompted several dose reductions and administration delays with limited success in diminishing the side effects.

The patient then decided to stop all medical treatment for his disease and try unconventional medicine instead. Much to our surprise, he returned six months later still in reasonable good shape, not willing to resume anti-neoplastic therapy, but to complain that even though he had apparently fully recovered from hand-foot syndrome, he was not allowed to receive a driver's license because he lacked fingerprints (Fig. 1). We wrote a letter explaining the medical reasons for that so he could get his license. By the time, his peripheral neuropathy was fairly better especially in the hands, as expected [5].

After that, he only returned a few months later when he was on the verge of liver failure and was admitted for palliative care and died.

This case highlights a rare condition that, even though not precisely a disease per se, may hinder patient's quality of life and must be recognised by the treating physician as a treatment-related side-effect.

\section{References}

1. Geyer CE, Forster J, Lindquist D et al. Lapatinib plus capecitabine for HER2-positive advanced breast cancer. N Engl J Med 2006; 355(26): 2733-2743.

2. Feliu J, Salud A, Escudero P et al. XELOX (capecitabine plus oxaliplatin) as first-line treatment for elderly patients over 70 years of age with advanced colorectal cancer. Br J Cancer 2006; 94(7): 969-975.

3. Cassidy J, Twelves C, Van CE et al. First-line oral capecitabine therapy in metastatic colorectal cancer: a favorable safety profile compared with intravenous 5-fluorouracil/leucovorin. Ann Oncol 2002; 13(4): 566-575.

4. Wong M, Choo SP, Tan EH. Travel warning with capecitabine. Ann Oncol 2009; 20(7): 1281. doi: 10.1093/annonc/mdp278.

5. Pachman DR, Qin R, Seisler DK et al. Clinical course of oxaliplatin-induced neuropathy: results from the randomized phase III trial N08CB (Alliance). J Clin Oncol. In press 2015.

\section{SOUTY̌̌̌ NA PODPORU AUTORSKÝCH TÝMO̊ PUBLIKUJÍĆ́CH V ZAHRANIČNÍ́CH ODBORNÝCH TITULECH}

\section{Odměna pro vítěze: 10000 Kč}

\section{Cíl soutěže:}

Podpořit renomé a prestiž časopisu Klinická onkologie - oficiálního časopisu ČOS ČLS JEP - u domácích i zahraničních autorů, lékařů a akademických pracovníků.

\section{Podmínky soutěže:}

1. Soutěž je určena autorským týmům, které publikují v zahraničních odborných titulech.

2. Do soutěže budou zařazeny práce publikované v zahraničních titulech od června 2014 do prosince 2015.

3. Ve svých článcích zaslaných $\mathrm{k}$ publikaci do zahraničního periodika budou autoři citovat práci, která byla otištěna v časopise Klinická onkologie (k vyhledání lze použít databáze www.pubmed.org nebo www.linkos.cz).

4. Do soutěže nebudou zařazeny autocitace.

5. Ze všech prací, které splní podmínky soutěěe, bude redakční radou vylosována jedna, jejiž autorský tým bude oceněn částkou 10000 Kč.

\section{KLINICKÁ ONKOLOGIE

